\title{
Aerial Observation of Atmospheric Nanoparticles on Fukue Island, Japan
}

\author{
Kwangyul Lee ${ }^{1}$, Indra Chandra ${ }^{1,3}$, Takafumi Seto ${ }^{1}$, Yayoi Inomata ${ }^{2 *}$, Masahiko Hayashi ${ }^{4}$, \\ Akinori Takami $^{5}$, Ayako Yoshino ${ }^{5}$, Yoshio Otani ${ }^{1}$ \\ ${ }^{1}$ Graduate School of Natural Science and Technology, Kanazawa University, Kanazawa, Ishikawa 920-1192, Japan \\ ${ }^{2}$ Institute of Nature and Environmental Technology, Kanazawa University, Kanazawa, Ishikawa 920-1192, Japan \\ ${ }^{3}$ Engineering Physics, School of Electrical Engineering, Telkom University, Bandung, Jawa Barat 40257, Indonesia \\ ${ }^{4}$ Faculty of Science, Fukuoka University, Jonan-ku, Fukuoka 814-0180, Japan \\ ${ }^{5}$ Center for Regional Environmental Research, National Institute for Environmental Studies, Tsukuba, Ibaraki 305-8506, \\ Japan
}

\begin{abstract}
New particle formation (NPF) in the East Asian region is strongly influenced by photochemical processes during the long-range transport of air pollutants. Our previous measurements (Seto et al., 2013; Chandra et al., 2016) relating to the incomplete and weak NPF (onset diameter $>10 \mathrm{~nm}$ ) on Fukue Island in Japan (downstream from the Asian continent) suggested nucleation in the upstream region. The vertical structure of atmospheric nanoparticle concentrations (particle size $>6 \mathrm{~nm}$ and altitude $<1.2 \mathrm{~km}$ ) during NPF was observed using a Kite-Plane at Fukue Island. Three different event types were identified through aerial observations (different vertical profiles of nanoparticles), ground-based measurements (the initial detected diameter of nanoparticles, NPF starting time, and dominant chemical component in $\mathrm{PM}_{1}$ ), and air mass backward trajectory analysis. A stronger NPF event (Event I: $>35,000$ particles $\mathrm{cm}^{-3}$ ) than in our previous measurements (from 2012 to $2016, \sim 20,000$ particles $\mathrm{cm}^{-3}$ ) with a particle size as small as $5 \mathrm{~nm}$, affected by the long-range transport of air pollutants under a high-pressure system, was detected. A sudden increase in particle number and $\mathrm{SO}_{2}$ concentrations with weak NPF caused by a change in the air mass origin (Event II: $<10,000$ particles $\mathrm{cm}^{-3}$ ) as well as no NPF with aged sulfate particles during conditions with low particle number and $\mathrm{SO}_{2}$ concentrations $(<0.15$ ppb) (Event III: $<2,000$ particles $\mathrm{cm}^{-3}$ ) were also observed.
\end{abstract}

Keywords: New particle formation; Vertical structure; Trans-boundary transport; East Asia.

\section{INTRODUCTION}

Secondary aerosol (SA) in East Asia exhibits complex features of condensation, evaporation, and chemical reactions due to the existence of large condensation and coagulation sinks (Kulmala et al., 2001; Dal Maso et al., 2002; Peng et al., 2017), high $\mathrm{SO}_{2}$ concentration (Zhang et al., 2009; Lu et al., 2010), large emission sources (Mönkkönen et al., 2005; Zhang et al., 2006) and long-range and trans-boundary transport (affecting other country located near the country of origin, e.g., air pollution) on westerly winds (Koike et al., 2003; Weber et al., 2003; Matsui et al., 2011). SA has different impacts on local air quality, human health and global radiation balance depending on chemical composition and particle size distribution (Penner et al., 2004; Davidson

\footnotetext{
* Corresponding author.

Tel.: +81-76-234-4825; Fax: +81-76-264-6239

E-mail address: yinomata@se.kanazawa-u.ac.jp
}

et al., 2005; Yu et al., 2010). New particle formation (NPF) is a key process that triggers SA formation via gas-toparticle conversion. NPF is associated with significant increase in the number concentration of nanoparticles (i.e., nucleation burst), and has been identified under various atmospheric conditions over East Asia. For example, Peng et al. (2017) and Kim et al. (2013, 2016) reported strong nucleation events in suburbs of Beijing and Xian in China and regional background sites in Korea, respectively. Several research groups also indicated the possibility of nucleation bursts during long-range transport in East Asia (Matsui et al., 2013; Seto et al., 2013; Chandra et al., 2016). Weber et al. (2003) noted the importance of nanoparticle measurement at high altitudes using aircraft observation to clarify NPF process under long-range transport of air pollutants in East Asia.

As other studies have noted, aircraft measurement represent a direct, in-situ method of examining the vertical and horizontal distribution of atmospheric parameters. Several aircraft measurement campaigns have been conducted to investigate the spatial distributions and 
physical and chemical properties of gases and particulate matter (PM) over East Asia (Hoell et al., 1997; Anderson et al., 2003; Bahreini et al., 2003; Hubert et al., 2003; Matsuki et al., 2003; Weber et al., 2003; Hatakeyama et al., 2004; Takegawa et al., 2004; Hatakeyama et al., 2011; Ren et al., 2012; Fujiwara et al., 2014; Hatakeyama et al., 2014; Lee et al., 2016; Hao et al., 2017). Weber et al. (2003) observed atmospheric nanoparticles (down to 3-4 nm), with results indicating highly concentrated nanoparticles in upstream or high-altitude regions. This could be related to our recent observation of incomplete and "weak" NPF (onset diameter above $10 \mathrm{~nm}$ ) in a downstream region, namely, Fukue Island in Japan (Chandra et al., 2016). However, large-scale aircraft measurement is expensive and requires high air speeds and altitudes $(>1 \mathrm{~km})$. Alternatively, lightweight unmanned aerial vehicles (UAVs) for conventional observation have been developed. In contrast to high-altitude manned-aircraft measurement studies, some studies have used UAVs to measure vertical and horizontal distributions of air pollutants at lower altitudes (Ramanathan et al., 2007; Ramana et al., 2010; Peng et al., 2015; Pistone et al., 2016; Schrod et al., 2017; Mamali et al., 2018). Wehner et al. (2010) studied NPF in Cabauw, the Netherlands, using a UAV and observed NPF in a turbulent layer before arriving at ground level. Altstädter et al. (2015) and Platis et al. (2016) investigated the vertical and horizontal distribution of ultrafine particles within the atmospheric boundary layer using UAVs with two condensation particle counters (CPCs) and studied the properties of the atmospheric boundary layer.

In this study, one type of the UAV, Kite-Plane (Sky Remote Co. Ltd.), was deployed to measure the vertical distribution $(<1.2 \mathrm{~km})$ of atmospheric nanoparticles $(>6 \mathrm{~nm})$ in the downstream region of the East Asian plume. The observation was combined with ground-based size distribution data (3$600 \mathrm{~nm}$ ) and meteorological parameters at the Fukue observation supersite, Japan.

\section{MEASUREMENT AND METHOD}

\section{Monitoring Site}

Atmospheric nanoparticle observation was conducted at a monitoring site located in Fukue Island $\left(32.8^{\circ} \mathrm{N}, 128.7^{\circ} \mathrm{E}\right)$, Japan. As shown in Fig. 1, Fukue Island is located at the southwestern boundary of Japan, and represent a suitable site for monitoring NPF and long-range transported pollutions from the Asian continent with less influence of local anthropogenic emission sources. The size distribution, chemical composition of submicron particles, $\mathrm{SO}_{2}, \mathrm{O}_{3}$, and meteorological parameters (temperature, relative humidity $(\mathrm{RH})$, wind speed and direction, and solar radiation) were measured at a ground-based monitoring site ( $G$ in Fig. 1). Previous researches (Seto et al., 2013; Takami et al., 2005) have described the details of the ground-based monitoring system. The aerial observation site (Location A in Fig. 1) is located at northwestern edge of Fukue Island, approximately $3.7 \mathrm{~km}$ from the ground-based monitoring site. Several aerial observation campaigns have been conducted at Fukue Island to measure $\mathrm{NO}_{\mathrm{x}}, \mathrm{SO}_{2}, \mathrm{O}_{3}$ (Hatakeyama et al., 2004, 2011; Fujiwara et al., 2014; Hatakeyama et al., 2014), CO

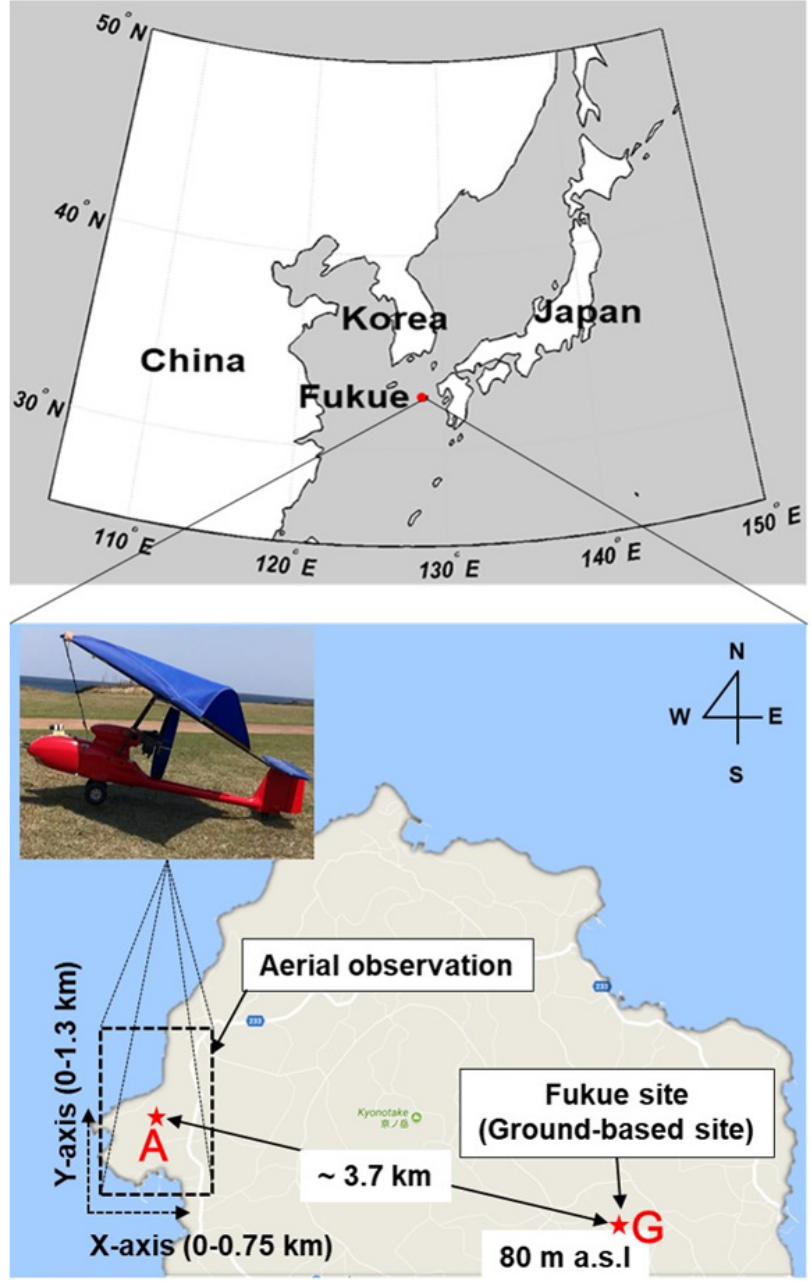

Fig. 1. The location of observation sites at Fukue Island (A: Aerial observation site and G: Ground-based monitoring site).

(Hatakeyama et al., 2011; Fujiwara et al., 2014; Hatakeyama et al., 2014), black carbon (BC) (Hatakeyama et al., 2011; Fujiwara et al., 2014) and the chemical composition of PM (Hatakeyama et al., 2004, 2011; Fujiwara et al., 2014; Hatakeyama et al., 2014) in East Asia. However, most of these measurements have focused on the chemical characteristics of outflow from the Asian continent and only limited information on the vertical distribution of nanoparticles in East Asia is available. In this study, a CPC was deployed for the first time in aerial observation to measure the vertical structure of nanoparticles at Fukue Island. The aerial observation site was selected to enable investigation of inflow air masses to Fukue Island.

\section{Aerial Observation (April 13-16, 2017)}

Intensive aerial observations at Fukue Island were carried out using the Kite-Plane. The Kite-Plane's maximum flight altitude is $3500 \mathrm{~m}$ above sea level with the maximum speed and payload of $35 \mathrm{~km}$ hour $^{-1}$ and up to $5 \mathrm{~kg}$, respectively (Yamashita et al., 2005; Hayashi et al., 2010) The detailed information regarding aerial observation is included in Table 2. A CPC (Model 3781, TSI Inc., USA) 
with a time resolution of 2 seconds was installed in the Kite-Plane to measure the vertical concentration of nanoparticles ( $>6 \mathrm{~nm}$ ). A tablet PC (M80T, ASUS, Taiwan) was used to control the CPC and save the measured data during aerial observation. The highest permitted flight altitude was $1200 \mathrm{~m}$ above sea level and three flights were allowed each day.

The performance of CPC for aerial observation was evaluated and compared with another CPC (Model 3775, TSI Inc., USA) in the laboratory using Ag particles (6$20 \mathrm{~nm}$ ) (not shown here). In addition, the effect of KitePlane exhaust was examined. After a preliminary test before the flights, an aerosol inlet for the CPC was installed at the front of the Kite-Plane to minimize the emission effect on particle concentration.

\section{Ground-Based Observation (April 13-16, 2017)}

Mobility size distribution and number concentration were measured using a long-scanning mobility particle sizer (long-SMPS) composed of a Long Differential Mobility Analyzer (DMA) (Model 3081, TSI Inc., USA) and a CPC (Model 3775, TSI Inc., USA) with a size range of 14-660 nm. For smaller nanoparticles $(2.5-60 \mathrm{~nm}$ and $1.4-30 \mathrm{~nm})$, a nano-SMPS (combination of Nano DMA (Model 3085, TSI Inc., USA) and Ultrafine CPC (UCPC; Model 3776, TSI Inc., USA)) and a 1nm SMPS (Model 3938E77, TSI Inc., USA), respectively, were used at the ground-based monitoring site. Meteorological parameters, including temperature, $\mathrm{RH}$, wind direction and speed, and solar radiation were measured by Chiba University, Japan. $\mathrm{SO}_{2}$ and $\mathrm{O}_{3}$ concentration were measured using an $\mathrm{SO}_{2}$ analyzer (Model 43i, Thermo Scientific, USA) and an $\mathrm{O}_{3}$ analyzer (Model 49i, Thermo Scientific, USA), respectively. In addition, an Aerosol Chemical Speciation Monitor (ACSM, Aerodyne Research Inc., USA) was used to measure the chemical composition (sulfate, nitrate, ammonium, organic, and chloride) of submicron $(<1 \mu \mathrm{m})$ particles. Detailed information on measurement parameters is described in Table 1.

For the investigation of the origin, vertical distribution, and pathway of air masses, air mass backward trajectory analysis was conducted using the Hybrid Single-Particle Lagrangian Integrated Trajectory model, version 4 (HYSPLIT4; Draxler and Rolph, 2003); 48-hour air mass backward trajectory analysis was performed at elevations of $80,200,400,600,800,1000$, and $1200 \mathrm{~m}$ arrival height above the ground level at both the ground-based and aerial observation sites). In addition, data on aerosol optical depth (AOD) over Northeast Asia were retrieved to investigate aerosol spatial distribution during the observation periods (http://worldview.earthdata.nasa.gov).

\section{RESULTS AND DISCUSSION}

\section{Data Overview and Meteorological Conditions}

Fig. 2 shows the temporal variation in particle number size distribution, chemical composition, $\mathrm{SO}_{2}$ concentration, and meteorological data. As shown in Fig. 2, the particle number concentration during the 4-day intensive measurement period (from $2.5 \mathrm{~nm}$ to $600 \mathrm{~nm}$ ) ranged from 197 to 32,110 particles $\mathrm{cm}^{-3}$ with an average of $2,965 \pm$ 1,948 particles $\mathrm{cm}^{-3}$. In calculating the average particle number concentration, 1-nm SMPS data were excluded because the 1-nm SMPS was only deployed during aerial observation. Our earlier studies (Seto et al., 2013; Chandra et al., 2016) reported that the average atmospheric nanoparticle concentration at Fukue Island was approximately 2,000 particles $\mathrm{cm}^{-3}$, without any inflow from outside Fukue Island. The average concentration of $\mathrm{PM}_{1}$ (the sum of ammonium, chloride, organic, nitrate, and sulfate measured by ACSM) was $8.23 \pm 3.72 \mu \mathrm{g} \mathrm{cm}^{-3}$ during intensive measurement, with the daily average fraction of submicron particles differing from day to day. $\mathrm{SO}_{2}$ concentration varied between 0.01 and $3.13 \mathrm{ppb}$, with an average of $0.75 \pm 0.65$ ppb. Based on the onset diameter (the starting diameter that could be measured by our system, i.e., SMPS) of NPF and growth $(<10 \mathrm{~nm}$ or $>10 \mathrm{~nm}), \mathrm{SO}_{2}$ concentration, the dominant chemical composition of submicron particles $(<1 \mu \mathrm{m})$, and air mass patterns, three different events were identified. During 4-day intensive measurements, long-range transport of air pollutants from northeast China with an NPF event was observed on April 13, 2017. On April 14, a high concentration of nanoparticles was detected due to a change of air mass origin starting at approximately 12:00. During the last two days (April 15-16), most of the air masses originated from the East China Sea and the particle number concentration decreased to 1,500 particles $\mathrm{cm}^{-3}$. Regarding meteorological parameters, the maximum solar radiation during the intensive measurement period was 842.2 (April 13), 915.6 (April 14), 798.1 (April 15), and 761.6 (April 16) $\mathrm{W} \mathrm{m}^{-2}$. Wind speed ranged from 0.2 to $6.6 \mathrm{~m} \mathrm{~s}^{-1}$, with an average of $1.6 \mathrm{~m} \mathrm{~s}^{-1}$, and the wind direction was northwesterly and/or southwesterly. According to the weather map (Fig. 3), high pressure was dominant on April 13 and 14 near Fukue Island (Figs. 3(a) and 3(b)), whereas the island was situated between high and low fronts on April 15 and 16 (Figs. 3(c) and 3(d)). The average temperature and relative humidity were $18.0^{\circ} \mathrm{C}$ and $73.0 \%$, respectively, during the measurement period.

During aerial observation, a total of 10 flights were conducted including one test flight without nanoparticle measurement. The flight area over Fukue Island was approximately $750 \times 1300 \mathrm{~m}^{2}$ (as shown in Fig. 1) for investigation of long-range transport from other regions as well as NPF events. The particle number concentration $(<1.2 \mathrm{~km})$ during aerial observation varied between 0.3 and 35,750 particles $\mathrm{cm}^{-3}$. The vertical distribution of atmospheric nanoparticles varied with the air mass origin and meteorological conditions. The details of each event are discussed in the following sections.

\section{Event I (Strong NPF with Long-range Transport of Air Pollutants under a High-pressure System)}

On April 13, a sudden increase of particle number concentration in the size range from the diameter of $5 \mathrm{~nm}$ started between 09:00 and 10:00 in the morning. Prior to this, the $\mathrm{SO}_{2}$ concentration increased from early in the morning (before sunrise), representing a sufficient precursor 


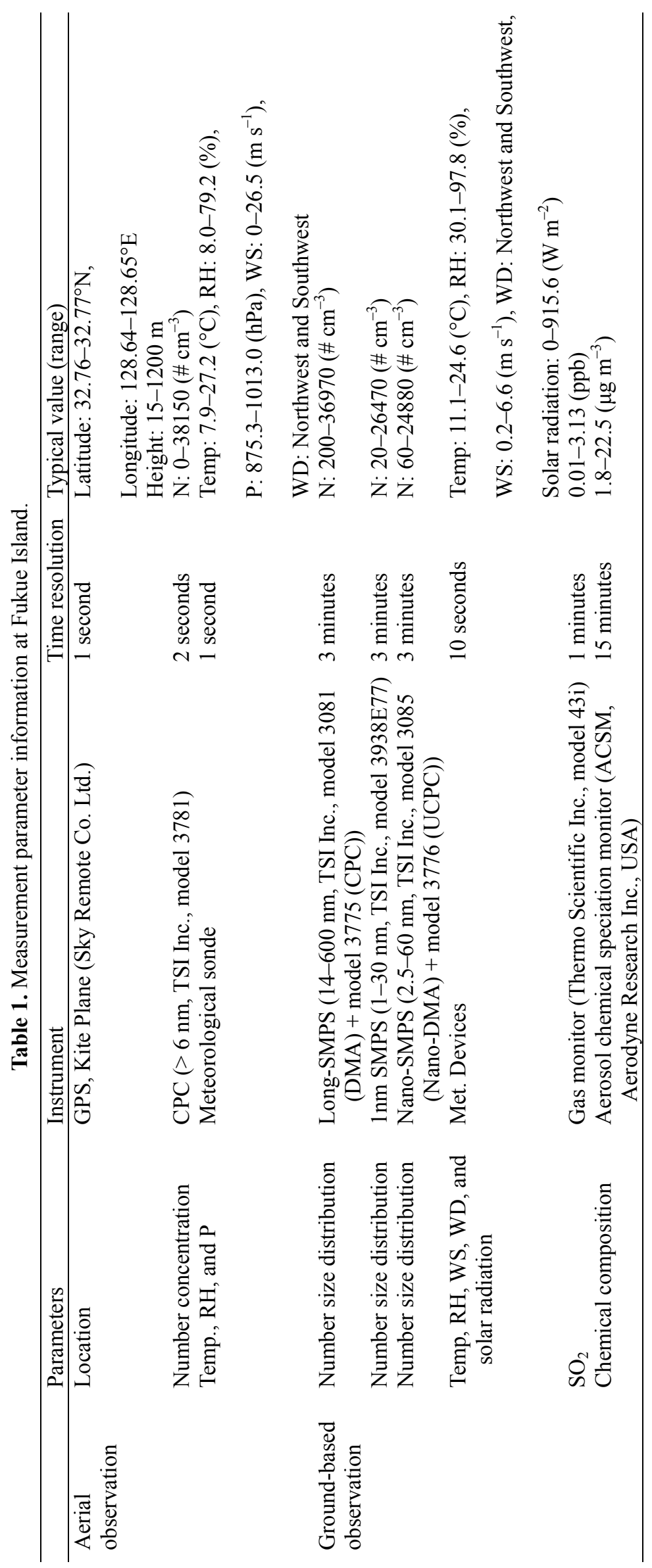




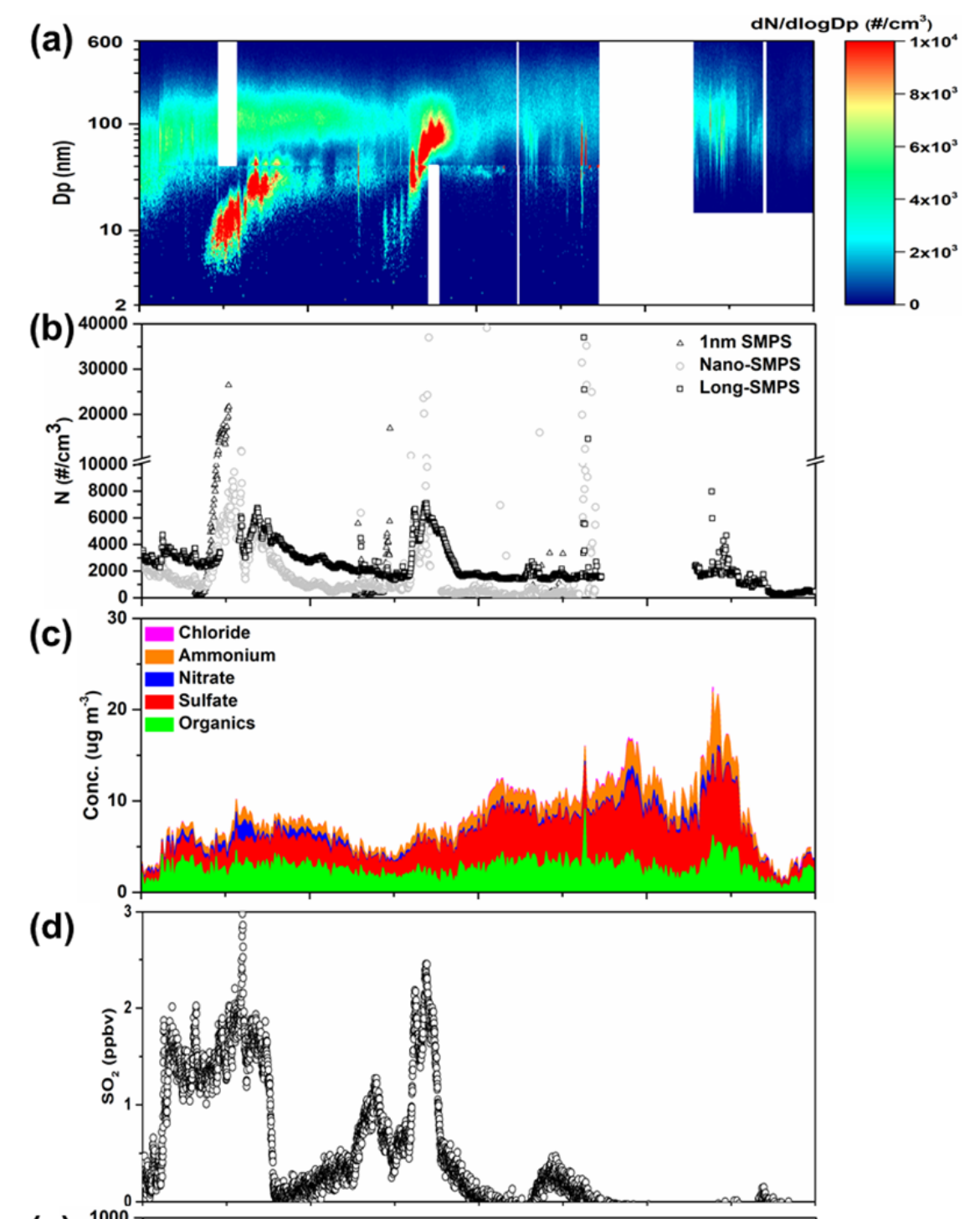

(e)

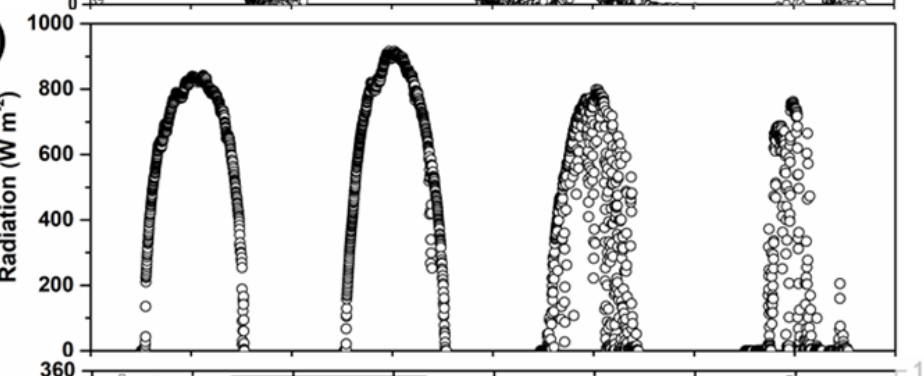

(f)

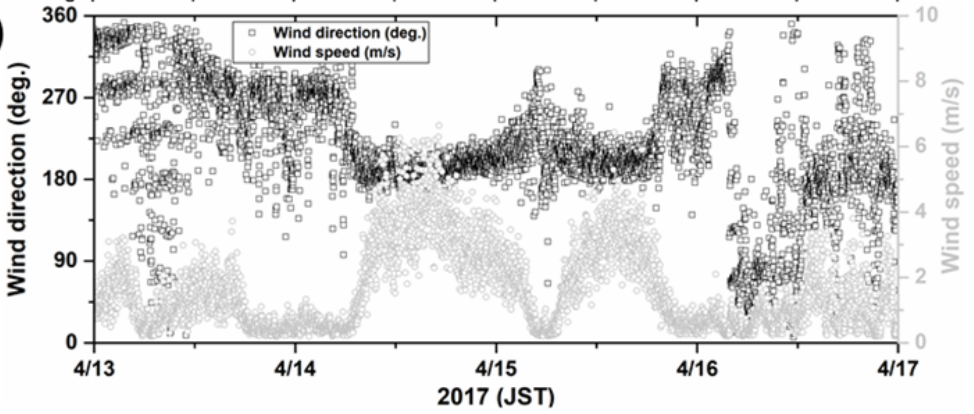

Fig. 2. Temporal variation of (a) contour plot of particle number size distribution, (b) particle number concentration by $1 \mathrm{~nm}$ SMPS, Nano SMPS, and long SMPS, (c) chemical composition (measured by ACSM), (d) $\mathrm{SO}_{2}$, (e) solar radiation, and (f) wind direction and wind speed observed at ground-based site in Fukue Island during the period from April 13 to 16 , 2017. 

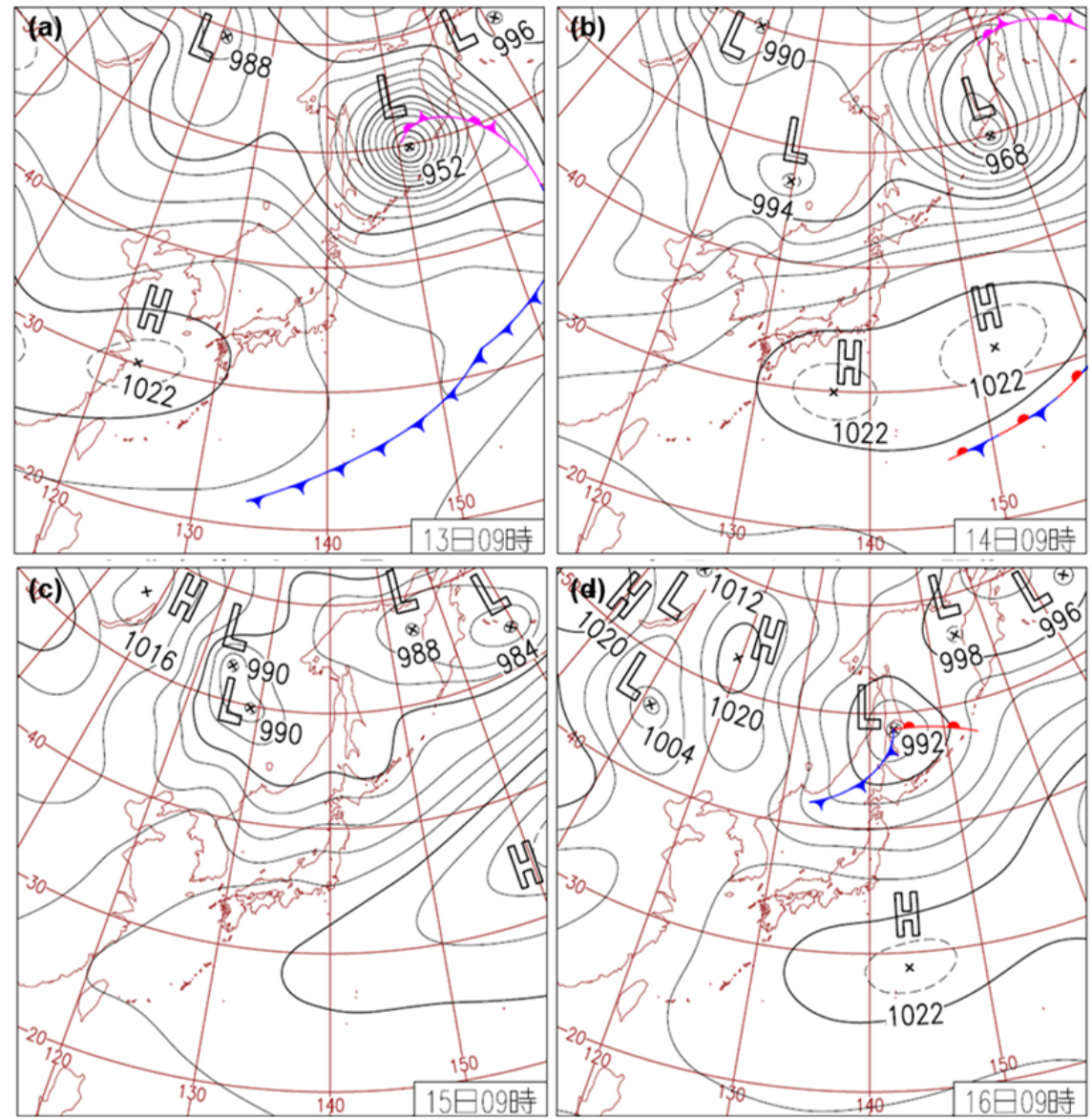

Fig. 3. Weather map (pressure map) during intensive measurement periods provided by Japan Meteorological Agency: (a) April 13, 09:00 JST, (b) April 14, 09:00 JST, (c) April 15, 09:00 JST, and (d) April 16, 09:00 JST (www.data.jma.go.jp).

of NPF. Moreover, strong solar radiation (max: $842.2 \mathrm{~W} \mathrm{~m}^{-2}$ ) contributed to NPF, providing suitable conditions for photochemical reactions in the ambient atmosphere (Seto et al., 2013; Chandra et al., 2016). In addition, subsequent particle growth of particles to several tens of nanometers after NPF was observed. This event was identified by favorable conditions for NPF with a high $\mathrm{SO}_{2}$ concentration (Fig. 2(d)) and strong solar radiation (Fig. 2(e)) under the effect of a high-pressure system (Fig. 3(a)). Many previous studies have shown that meteorological conditions such as a clear sky with few clouds, high solar radiation intensity, and no precipitation under a high-pressure system can affect NPF and particle growth in various regions (Covert et al., 1996; Wehner et al., 2004; Chandra et al., 2016; Kim et al., 2016). This high concentration of ultrafine particles $(<100 \mathrm{~nm}$ ) remained for 12 hours (until 22:00; Fig. 2(a)). Apart from the NPF event, high concentrations in other nanoparticle size ranges $(\sim 100 \mathrm{~nm})$ were observed throughout the day; these may have been preexisting atmospheric particles. Regarding the chemical compositions in $\mathrm{PM}_{1}$ during the first day of intensive measurement, organics were predominant, followed by sulfate, nitrate, and ammonium. Based on air mass backward trajectory analysis, most of the air masses originated from polluted regions (northeast China, Fig. 4(b)). Two aerial observations (11:55-12:35 and 15:00-15:40) were conducted using the Kite-Plane with a
CPC. The vertical distribution of atmospheric nanoparticles, potential temperature, water vapor mixing ratio and the air masses recorded during the first aerial observation are shown in Figs. 4 and 5, respectively. During the first aerial observation, the particle number concentration $(2.5-600 \mathrm{~nm})$ at ground level was between 15,000 and 20,000 particles $\mathrm{cm}^{-3}$, while particle number concentration $(>6 \mathrm{~nm})$ increased to approximately 36,000 particles $\mathrm{cm}^{-3}$ at $400-\mathrm{m}$ level (Fig. 4(a)). Above $400 \mathrm{~m}$, the particle number concentration decreased to 2,000 particles $\mathrm{cm}^{-3}$. The change in boundarylayer height (between 600 and $800 \mathrm{~m}$ ) determined by the water vapor mixing ratio affected the vertical distribution of nanoparticles during aerial observation. The particle number concentration up to a height of $800 \mathrm{~m}$ was greater during the first flight than during the second, with the maximum difference in particle concentration $(\sim 24,000$ particles $\mathrm{cm}^{-3}$ ) observed at approximately $400 \mathrm{~m}$. This may have been caused by meteorological conditions such as vertical mixing, the boundary-layer height, or other factors (Table 2). However, from 900 to $1200 \mathrm{~m}$, the particle number concentration was greater during the second flight, possibly because of a change of height in the air mass origin (Fig. 5(c)). Although the air mass origin at 80, 200, and $400 \mathrm{~m}$ was quite different during the first and second flights on April 13, most air masses moved near ground level. However, air masses above $600 \mathrm{~m}$ were less affected 
(a)

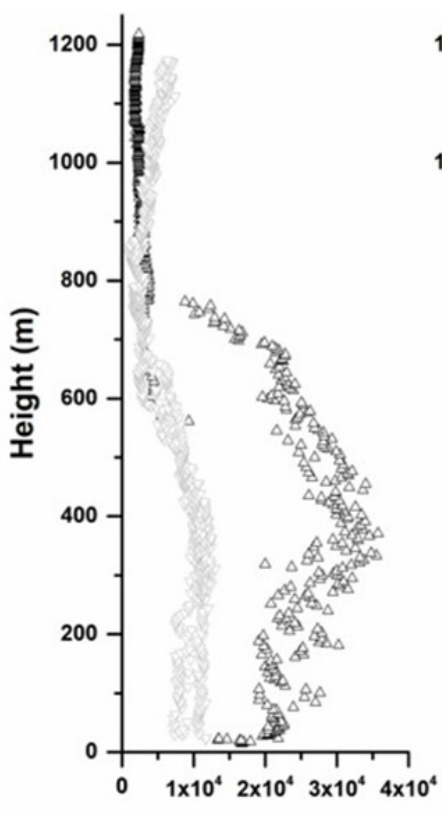

Number conc. $\left(\mathrm{cm}^{-3}\right)$
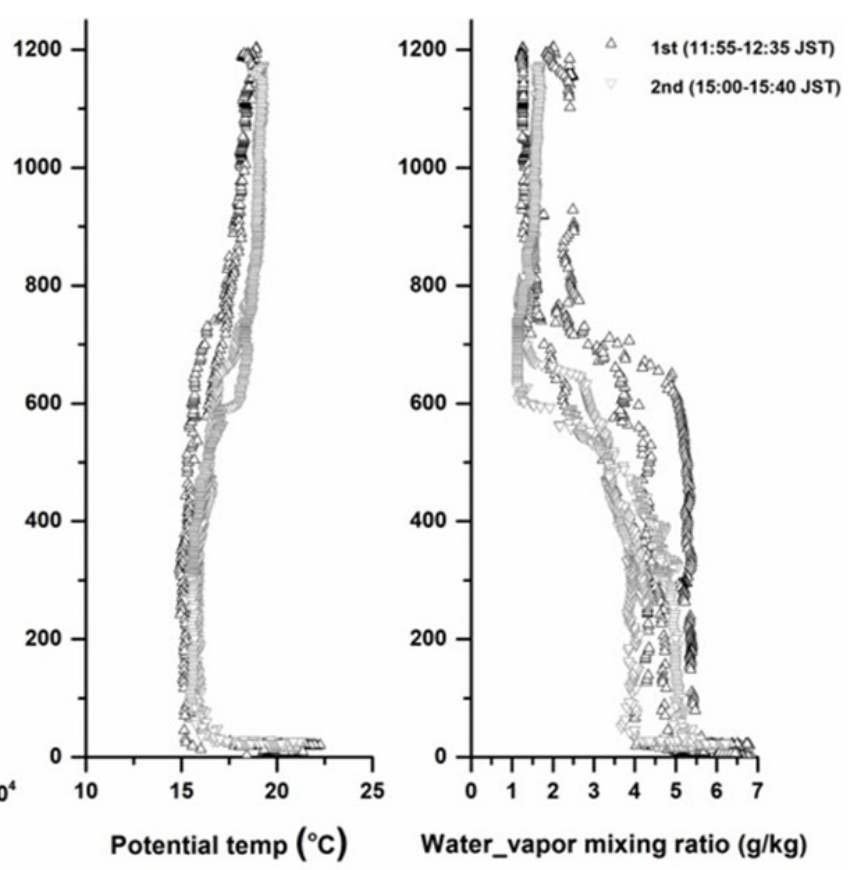

(b)

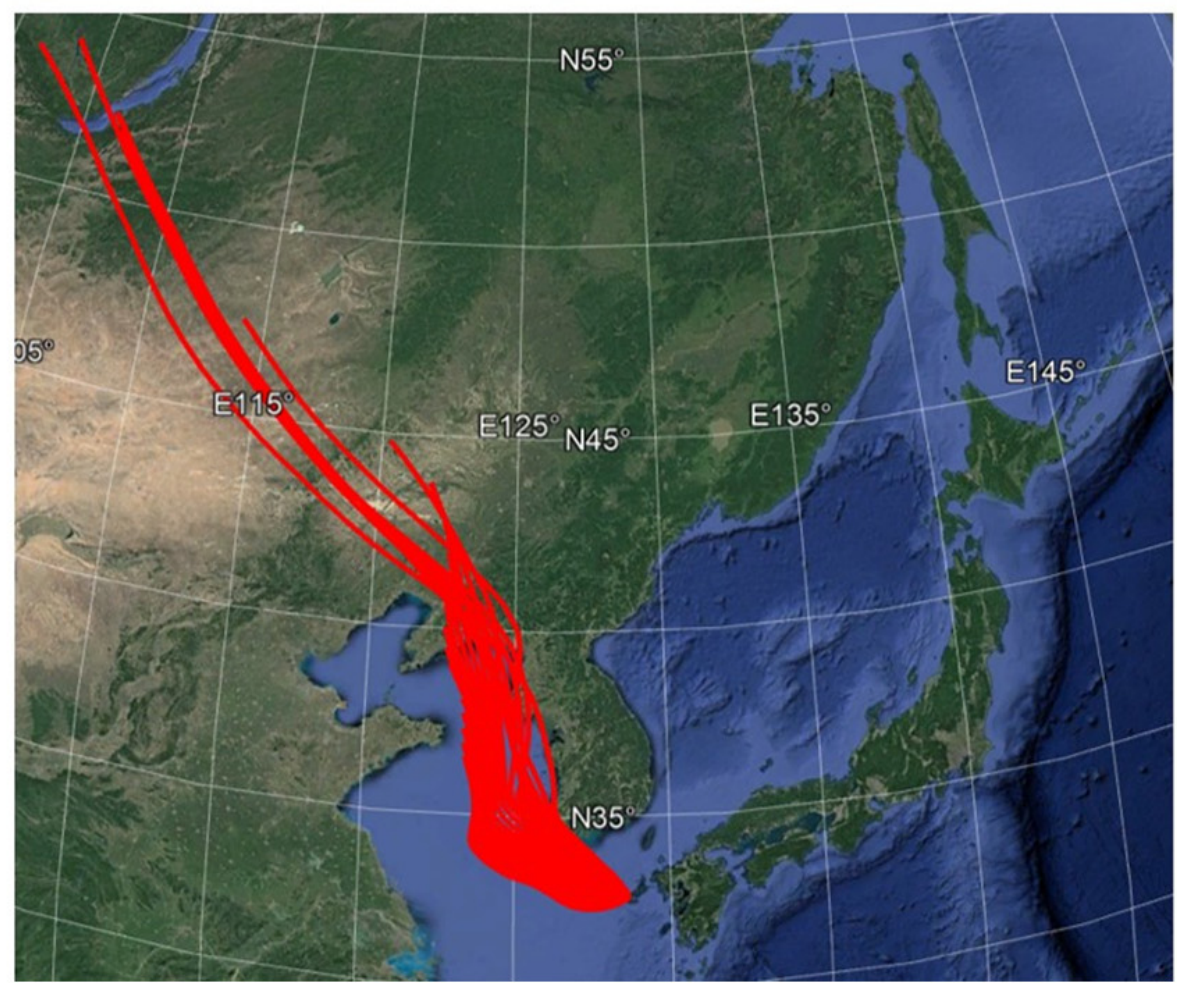

Fig. 4. Vertical distribution of (a) atmospheric nanoparticles (left), potential temperature (middle), and water vapor mixing ratio (right) during aerial observation and (b) air mass backward trajectory on April 13, 2017 (JST).

by the surface concentration during transport (Figs. 5(a) and $5(\mathrm{~b})$ ). Based on the vertical distribution of air mass backward trajectory during aerial observation, most air masses below $400 \mathrm{~m}$ originated from below $1 \mathrm{~km}$, and vertical movement within $300 \mathrm{~m}$ was observed (Fig. 5(a)). Therefore, we can speculate that various air pollutants, including organics and $\mathrm{SO}_{2}$, were transported from polluted regions that many nanoparticles could be formed during long-range transport.
During the second aerial observation in the afternoon, a higher particle number concentration $\left(>8,000\right.$ particles $\left.\mathrm{cm}^{-3}\right)$ up to $500 \mathrm{~m}$ was observed (Fig. 4(a)). In addition, most air masses below $400 \mathrm{~m}$ moved near ground level. In light of other studies employing air mass backward trajectory analysis, this high concentration could have been due to long-range transport of anthropogenic sources from northeast China and/or Inner Mongolia (Zhang et al., 2009; Chandra et al., 2016). Moreover, an increased particle number 

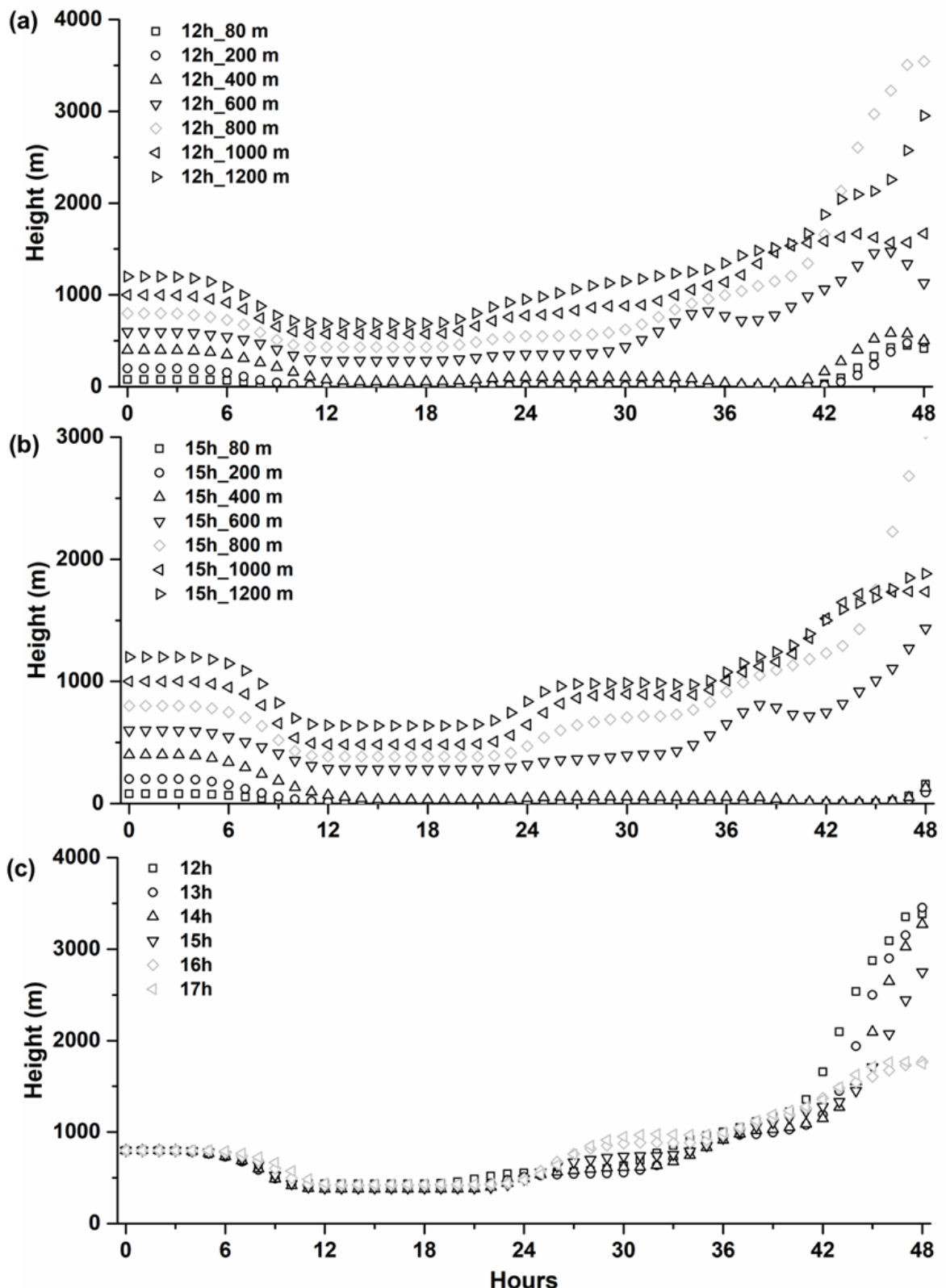

Fig. 5. Air mass backward trajectory during aerial observation on April 13, 2017: (a) $1^{\text {st }}$ flight (11:55-12:35 JST), (b) $2^{\text {nd }}$ flight (15:00-15:40 JST), and (c) air mass backward trajectory before and after during $2^{\text {nd }}$ aerial observation at $800 \mathrm{~m}$.

concentration was observed in the afternoon above $800 \mathrm{~m}$, possibly caused by the inflow of different air masses. At $800 \mathrm{~m}$, the air mass origin changed from over 3000 to approximately $1500 \mathrm{~m}$ between 15:00 and 16:00 (JST) (Fig. 5(c)). This height change may have caused vertical aerosol mixing in the source region, thereby influencing the increase in particle number concentration over $800 \mathrm{~m}$ (Fig. 5(c))

\section{Event II (Weak NPF with Change of Air Mass Origin on April 14)}

Fig. 6 shows the vertical distribution of atmospheric nanoparticles, potential temperature, water vapor mixing ratio and air masses on April 14. In the morning, the average particle number concentration at the ground site was less than 3,000 particles $\mathrm{cm}^{-3}$. The particle number concentration also decreased with increasing flight altitude during the two aerial observations before noon. However, the particle number concentration in the size range from 20 to $100 \mathrm{~nm}$ began increasing at $14: 00$ and continued until 20:00 (Fig. 2; average number concentration between 14:00 and 20:00 JST was 5,273 particles $\mathrm{cm}^{-3}$ ) at the ground site. In addition, the $\mathrm{SO}_{2}$ concentration increased with the particle number concentration to $2.50 \mathrm{ppb}$ between 16:00 and 17:00 JST. Based on $\mathrm{SO}_{2}$ emissions data (700 $\mathrm{t}_{\text {day }}{ }^{-1}$ near Event II at Mt. Aso in Kyushu, Japan) and air mass backward trajectory analysis, the change of air mass origin (from the Yellow Sea to the Korean Peninsula and Kyushu) as well as $\mathrm{SO}_{2}$ emitted from volcanic sources in Kyushu and anthropogenic local emissions over these areas could 
(a)
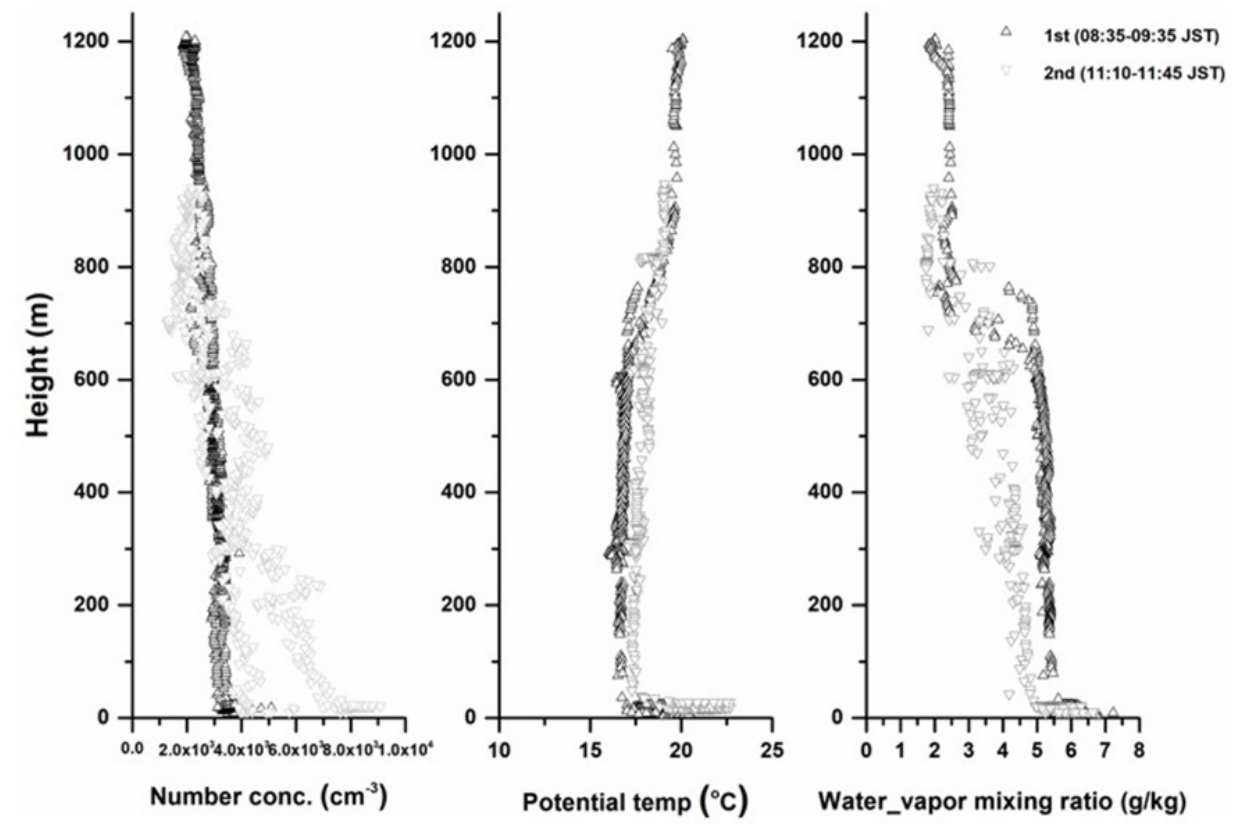

(b)

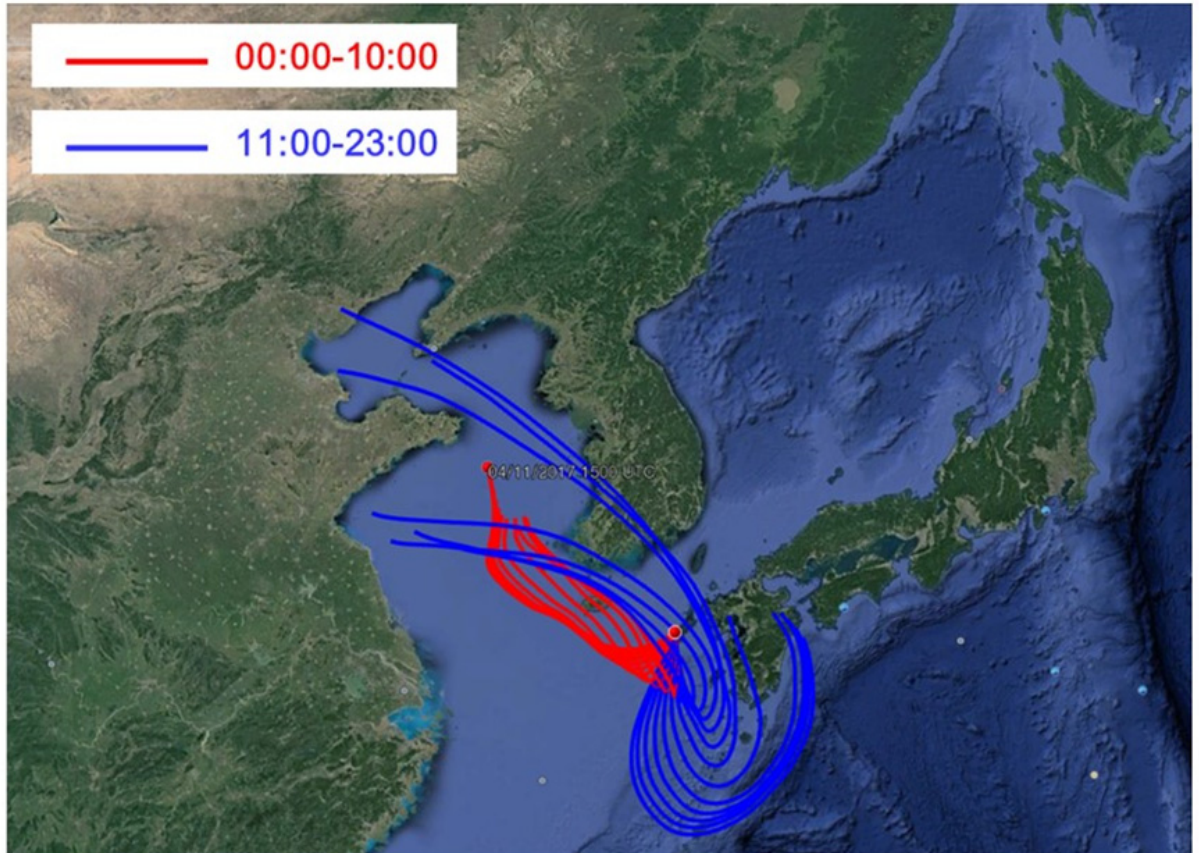

Fig. 6. Vertical distribution of (a) atmospheric nanoparticles (left), potential temperature (middle), and water vapor mixing ratio (right) during aerial observation and (b) air mass backward trajectory on April 14, 2017 (JST).

have influenced the increase in particle number and $\mathrm{SO}_{2}$ concentrations at the measurement site. Unfortunately, no aerial observation could be conducted due to strong winds in the afternoon of April 14. In contrast with the situation observed on April 13, the onset diameter of nanoparticles on this day started at approximately $10 \mathrm{~nm}$, suggesting that these particles could have formed during transport or in the upstream region over the ground measurement site.

\section{Event III (No NPF with Highly Aged Sulfate Particles on April 15 and 16)}

The vertical distribution of atmospheric nanoparticles, potential temperature and water vapor mixing ratio on April 15 and air mass backward trajectory on April 15 and 16 are shown in Figs. 7 and 8, respectively. During the last two days of intensive measurement, the average particle number concentration at the ground-based site was 1,812 and 1,207 particles $\mathrm{cm}^{-3}$, respectively. Data measured using the Nano SMPS was not available from the afternoon of April 15 to the end of intensive measurement due to a technical problem; therefore, only long-SMPS data was used in the analysis of atmospheric nanoparticles at this time. Although the particle number concentration was less than 2,000 particles $\mathrm{cm}^{-3}$ and the $\mathrm{SO}_{2}$ concentration mostly 


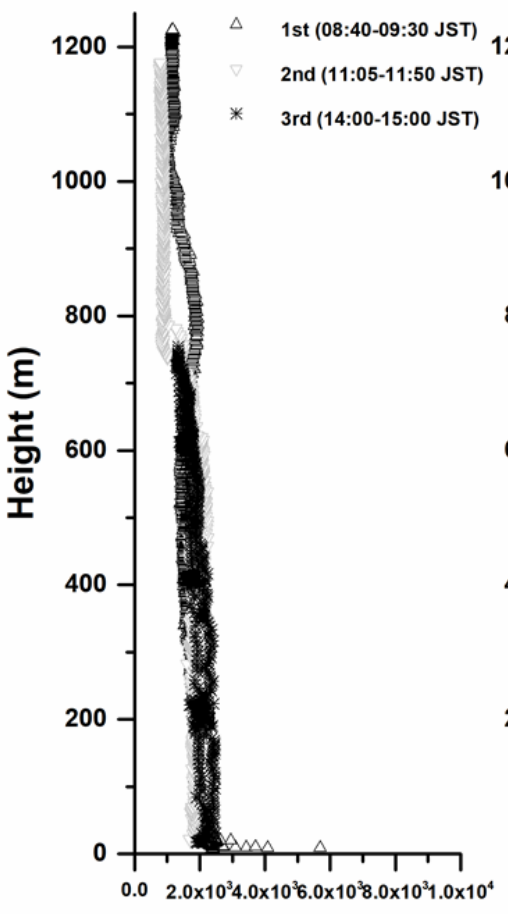

Number conc. $\left(\mathrm{cm}^{-3}\right)$
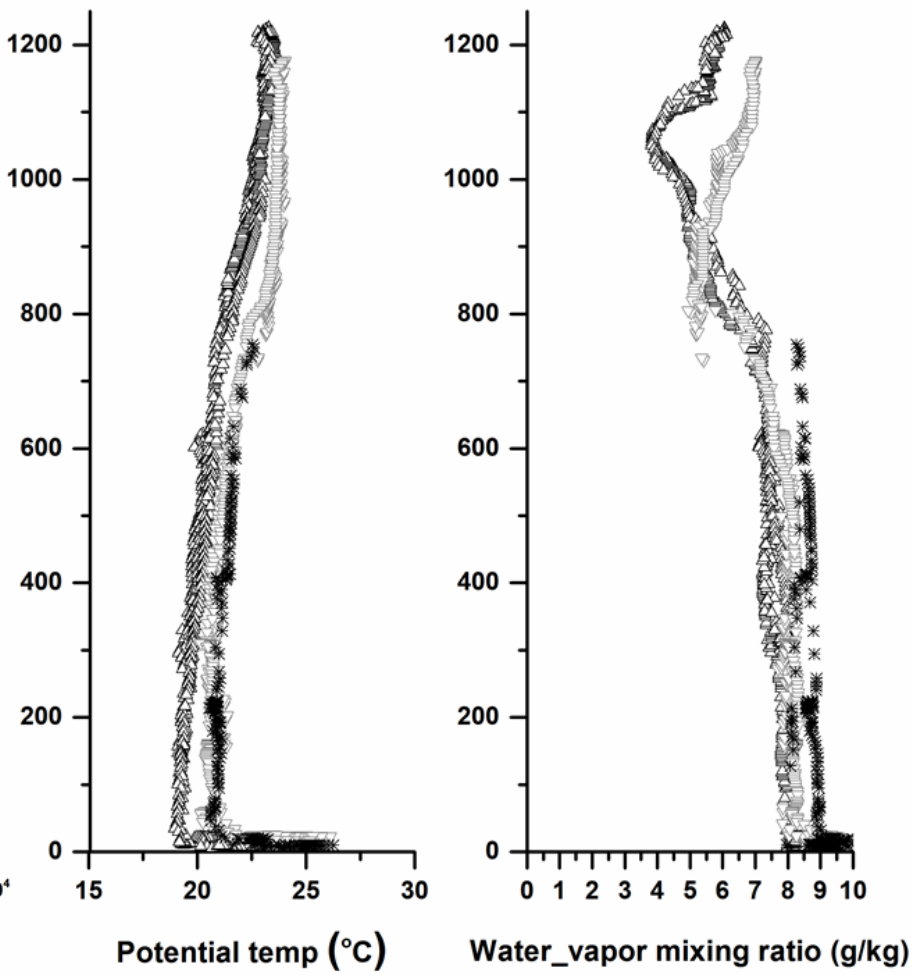

Fig. 7. Vertical distribution of (a) atmospheric nanoparticles (left), potential temperature (middle), and water vapor mixing ratio (right) during aerial observation on April 15, 2017 (JST).

(a)

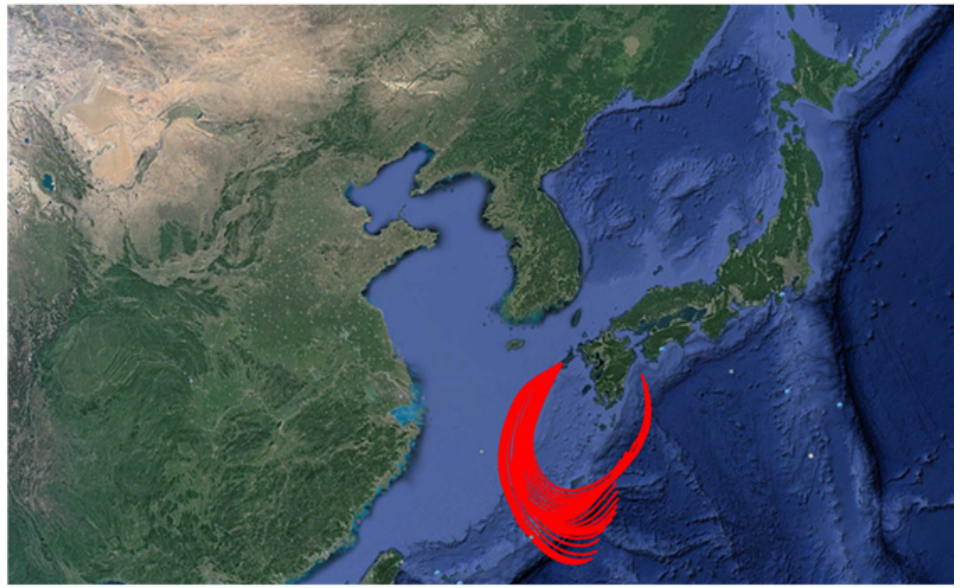

(b)

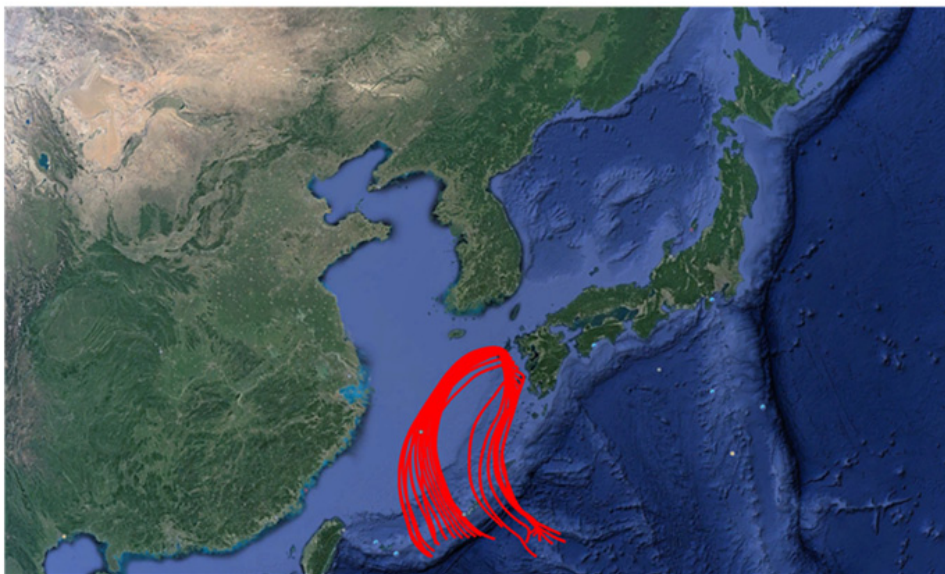

Fig. 8. Air mass backward trajectory on (a) April 15 and (b) April 16, 2017 (JST). 
lower than the instrument's detection limit, the sulfate concentration in submicron size $(<1 \mu \mathrm{m})$ increased during these two days. The average sulfate concentration was $4.98 \mu \mathrm{g} \mathrm{m}^{-3}$, and with the non-sea-salt (nss) sulfate fraction over 0.95 during the last two days of measurement. Aerial observations were conducted five times during the last two days (three times on April 15 and twice on April 16). The particle number concentration was mainly 2,000 particles $\mathrm{cm}^{-3}$ or less, and no increase of particle number concentration related to increasing sulfate could be observed during aerial observation. The average $\mathrm{SO}_{2}$ concentration at the ground site was $0.15 \mathrm{ppb}$. According to air mass backward trajectory analysis, most air masses originated over the East China Sea and their movement was slower than on the previous two days (April 13-14). Satellite-retrieved AOD data was used to investigate the high sulfate concentration. Starting on April 15, high aerosol loading was observed over southeast China, including Shanghai. In addition, these high-concentration aerosols were observed moving over the East China Sea on April 15 and 16. Based on air mass backward trajectory (relatively slow air mass speed) and AOD data (over the southeast China region) (Fig. S1), the high aerosol loadings observed over southeast China could have affected the measurement site on April 15 and 16. To investigate particle aging, the ratio between sulfate $\left(\mathrm{SO}_{4}{ }^{2-}\right)$ and the sum of sulfur dioxide $\left(\mathrm{SO}_{2}\right)$ and sulfate $\left(\mathrm{SO}_{4}{ }^{2-}\right)$ was calculated, and found to be close to 1 on April 15 and 16 , suggesting that the aerosols aged during the transport. Moreover, relatively low moving speed of air masses over the East China Sea could have ensured sufficient residence time for particle aging.

\section{Comparison of the Vertical Distribution of Atmospheric Nanoparticles}

Table 2 lists the characteristics of the three events during intensive measurement in April 2017. The vertical distribution of atmospheric nanoparticles, potential temperature, and water vapor mixing ratio are shown in Figs. 4, 6, and 7 for each event. The temperature lapse rate ranged from 0.6 to $0.8^{\circ} \mathrm{C}$ per $100 \mathrm{~m}$. RH mainly increased with height from the ground to a level near the mixed layer (between 600 and $1000 \mathrm{~m}$ ), then rapidly decreased within the mixed layer. The mixed-layer height varied according to different days and observation times. In most cases, the particle number concentration decreased with increasing height from the ground, except on April 13. During the ascent and descent of the first flight on April 13, the maximum particle number concentration was observed near $400 \mathrm{~m}$, and was three times higher $\left(\sim 36,000\right.$ particles $\left.\mathrm{cm}^{-3}\right)$ than that measured at the ground site. Although it is difficult to distinguish an NPF event based only on aerial observation data, higher particle number concentration (36,000 particles $\mathrm{cm}^{-3}$ near $\left.400 \mathrm{~m}\right)$ than that measured on the ground was observed. In our earlier studies on five years of measurement, the maximum particle number concentration (3-670 nm) in ground-based measurement was less than 20,000 particles and such a high concentration $\left(36,000\right.$ particles $\left.\mathrm{cm}^{-3}\right)$ was not observed. According to combined ground-based measurement and aerial observation

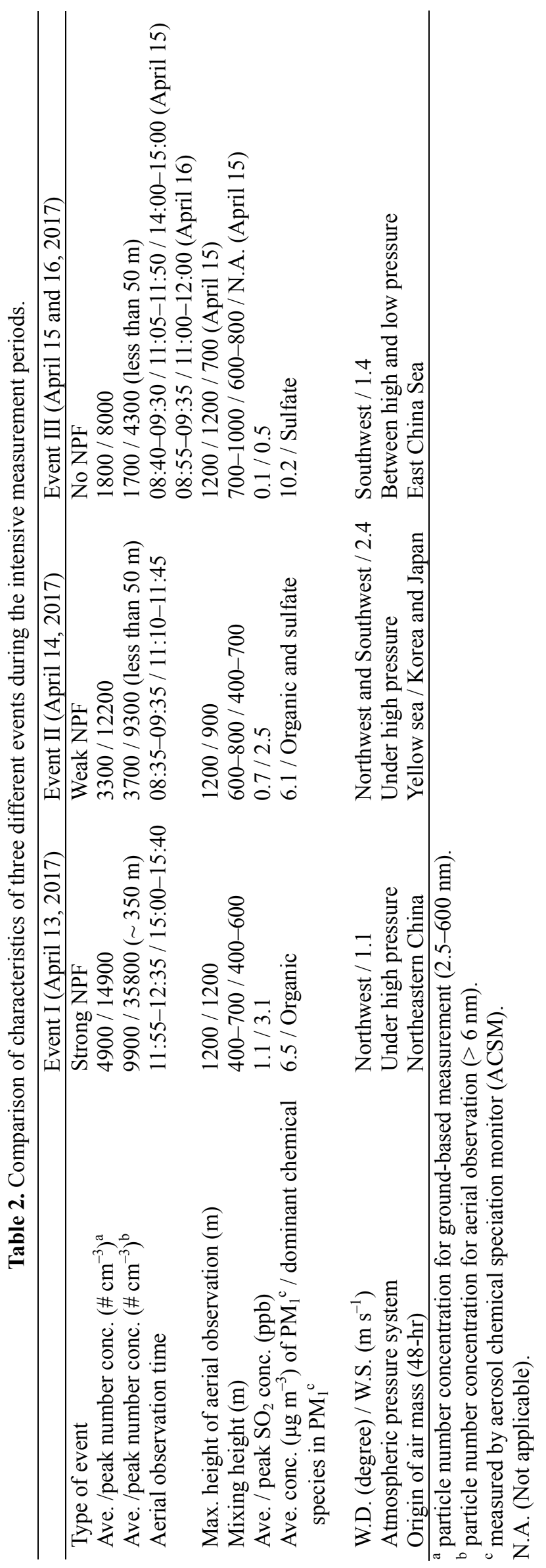


data, NPF could have contributed to a large high-altitude particle concentration or occurred during transport and/or in the upstream region before reaching Fukue Island. Furthermore, the increased particle number concentration above $800 \mathrm{~m}$ that was observed during the second flight on April 13 was caused by the inflow of different transboundary air masses (Fig. 5). At a height of $800 \mathrm{~m}$, the air mass origin changed from over $3000 \mathrm{~m}$ to approximately $1500 \mathrm{~m}$ between 15:00 and 16:00 (JST), which could have caused vertical aerosol mixing in the source region and thus influenced the particle number concentration at this altitude. The characteristics of the three different events during the intensive measurement periods are summarized in Table 2. The information on ground-based aerosol size distribution and vertical variations in particle number concentration may help reduce uncertainty when estimating radiative forcing caused by aerosols.

\section{CONCLUSIONS}

In this study, the vertical distributions and characteristics of atmospheric nanoparticles were investigated from April 13 to April 16, 2017, at the Fukue observation supersite in Japan. During 4-day intensive measurements, three different events were recorded via aerial observation and at a groundbased site. These events were analyzed using combined aerial and ground-based observation data. On April 13, NPF and an increased nanoparticle number concentration below $400 \mathrm{~m}$ were detected at the ground-based site and via aerial observation, respectively. In addition, an increased nanoparticle concentration between 800 and 1,200 m due to a change in the altitude of the air mass origin was identified via aerial observation. A sudden change in the origin of the air mass over the polluted area similarly caused increased nanoparticle numbers and $\mathrm{SO}_{2}$ concentrations on the afternoon of April 14. A high concentration of sulfate in the $\mathrm{PM}_{1}$ without increased $\mathrm{SO}_{2}$ and nanoparticle concentrations was detected both at the ground-based site and via aerial observation on April 15 and 16. Starting on April 15, high aerosol loading over southeast China and aerosol transport over the East China Sea were observed. Most high-sulfate particles were affected by southeast China, including Shanghai, and these particles were highly aged during long-range transport over the East China Sea. These findings reveal the applicability of our UAV for detecting NPF processes in the downstream region of East Asia.

\section{ACKNOWLEDGEMENT}

This work was supported by JST Strategic Basic Research Programs (Grant Number JPMJCR18H4), JSPS KAKENHI Grant Number 15H04171 and The Environment Research and Technology Development Fund (ERTDF) from Ministry of Environment, Japan (5-1452, 2-1403, and S-12). Also, this research was supported by Basic Science Research Program through the National Research Foundation of Korea (NRF) funded by the Ministry of Education (NRF2018R1A6A3A03012663).

\section{SUPPLEMENTARY MATERIAL}

Supplementary data associated with this article can be found in the online version at http://www.aaqr.org.

\section{REFERENCES}

Altstädter, B., Platis, A., Wehner, B., Scholtz, A., Wildmann, N., Hermann, M., Käthner, R., Baars, H., Bange, J. and Lampert, A. (2015). ALADINA - An unmanned research aircraft for observing vertical and horizontal distributions of ultrafine particles within the atmospheric boundary layer. Atmos. Meas. Tech. 8: 1627-1639.

Anderson, T.L., Masonis, S.J., Covert, D.S., Ahlquist, N.C., Howell, S.G., Clarke, A.D. and McNaughton, C.S. (2003). Variability of aerosol optical properties derived from in situ aircraft measurements during ACE-Asia. $J$. Geophys. Res. 108: 8647.

Bahreini, R., Jimenez, J.L., Wang, J., Flagan, R.C., Seinfeld, J.H., Jayne, J.T. and Worsnop, D.R. (2003). Aircraftbased aerosol size and composition measurements during ACE-Asia using an Aerodyne aerosol mass spectrometer. J. Geophys. Res. 108: 8645.

Chandra, I., Kim, S., Seto, T., Otani, Y., Takami, A., Yoshino, A., Irei, S., Park, K., Takamura, T. and Kaneyasu, N. (2016). New particle formation under the influence of the long-range transport of air pollutants in East Asia. Atmos. Environ. 141: 30-40.

Covert, D., Kapustin, V., Bates, T. and Quinn, P. (1996). Physical properties of marine boundary layer aerosol particles of the mid-Pacific in relation to sources and meteorological transport. J. Geophys. Res. 101: 69196930.

Dal Maso, M., Kulmala, M., Lehtinen, K.E., Mäkelä, J., Aalto, P. and O'Dowd, C. (2002). Condensation and coagulation sinks and formation of nucleation mode particles in coastal and boreal forest boundary layers. $J$. Geophys. Res. 107: PAR 2-1-PAR 2-10.

Davidson, C.I., Phalen, R.F. and Solomon, P.A. (2005). Airborne particulate matter and human health: A review. Aerosol Sci. Technol. 39: 737-749.

Draxler, R. and Rolph, G. (2003). Hysplit (Hybrid SingleParticle Lagrangian Integrated Trajectory) Model Access Via Noaa Arl Ready. Noaa Air Resources Laboratory, Silver Spring, Md. Dostupno na: http://ready. arl. noaa.g ov/HYSPLIT. Php, Last Access: 06 June 2010.

Fujiwara, H., Sadanaga, Y., Urata, J., Masui, Y., Bandow, H., Ikeda, K., Hanaoka, S., Watanabe, I., Arakaki, T. and Kato, S. (2014). Aerial observation of nitrogen compounds over the East China Sea in 2009 and 2010. Atmos. Environ. 97: 462-470.

Hao, J., Yin, Y., Kuang, X., Chen, J., Yuan, L., Xiao, H., Li, Z., Pu, M., Wang, J. and Zhou, X. (2017). Aircraft measurements of the aerosol spatial distribution and relation with clouds over Eastern China. Aerosol Air Qual. Res. 17: 3230-3243.

Hatakeyama, S., Takami, A., Sakamaki, F., Mukai, H., Sugimoto, N., Shimizu, A. and Bandow, H. (2004). 
Aerial measurement of air pollutants and aerosols during 20-22 March 2001 over the East China Sea. J. Geophys. Res. 109: D13304.

Hatakeyama, S., Hanaoka, S., Ikeda, K., Watanabe, I., Arakaki, T., Sadanaga, Y., Bandow, H., Kato, S., Kajii, Y. and Sato, K. (2011). Aerial observation of aerosols transported from East Asia--Chemical composition of aerosols and layered structure of an air mass over the East China Sea. Aerosol Air Qual. Res. 11: 497-507.

Hatakeyama, S., Ikeda, K., Hanaoka, S., Watanabe, I., Arakaki, T., Bandow, H., Sadanaga, Y., Kato, S., Kajii, Y. and Zhang, D. (2014). Aerial observations of air masses transported from East Asia to the Western Pacific: Vertical structure of polluted air masses. Atmos. Environ. 97: 456-461.

Hayashi, M., Kamiya, Y., Ozuka, K., Yamashita, K., Higashi, H., Ashida, M., Okabe, K. and Shigeta, T. (2010). Mineral Particles internally mixed with sea salt over Karatsu Bay, Southwest of Japan, observed with a small unmanned aerial vehicle. J. Fukuoka Univ. Sci. Learn. 40: 245-253.

Hoell, J., Davis, D., Liu, S., Newell, R., Akimoto, H., McNeal, R. and Bendura, R. (1997). The pacific exploratory mission-west phase B: February-March 1994. J. Geophys. Res. 102: 28223-28239.

Huebert, B.J., Bates, T., Russell, P.B., Shi, G., Kim, Y.J., Kawamura, K., Carmichael, G. and Nakajima, T. (2003). An overview of ACE-Asia: Strategies for quantifying the relationships between Asian aerosols and their climatic impacts. J. Geophys. Res. 108: 8633.

Kim, Y., Yoon, S.C., Kim, S.W., Kim, K.Y., Lim, H.C. and Ryu, J. (2013). Observation of new particle formation and growth events in Asian continental outflow. Atmos. Environ. 64: 160-168.

Kim, Y., Kim, S.W., Yoon, S.C., Park, J.S., Lim, J.H., Hong, J., Lim, H.C., Ryu, J., Lee, C.K. and Heo, B.H. (2016). Characteristics of formation and growth of atmospheric nanoparticles observed at four regional background sites in Korea. Atmos. Res. 168: 80-91.

Koike, M., Kondo, Y., Kita, K., Takegawa, N., Masui, Y., Miyazaki, Y., Ko, M., Weinheimer, A., Flocke, F. and Weber, R. (2003). Export of anthropogenic reactive nitrogen and sulfur compounds from the East Asia region in spring. J. Geophys. Res. 108: 8789.

Kulmala, M., Maso, M.D., Mäkelä, J., Pirjola, L., Väkevä, M., Aalto, P., Miikkulainen, P., Hämeri, K. and O'dowd, C. (2001). On the formation, growth and composition of nucleation mode particles. Tellus B 53: 479-490.

Lee, G., Oh, H.R., Ho, C.H., Kim, J., Song, C.K., Chang, L.S., Lee, J.B. and Lee, S. (2016). Airborne measurements of high pollutant concentration events in the free troposphere over the West Coast of South Korea between 1997 and 2011. Aerosol Air Qual. Res. 16: 1118-1130.

Lu, Z., Streets, D.G., Zhang, Q., Wang, S., Carmichael, G.R., Cheng, Y.F., Wei, C., Chin, M., Diehl, T. and Tan, Q. (2010). Sulfur dioxide emissions in China and sulfur trends in East Asia since 2000. Atmos. Chem. Phys. 10: 6311-6331.

Mamali, D., Marinou, E., Sciare, J., Pikridas, M.,
Kokkalis, P., Kottas, M., Binietoglou, I., Tsekeri, A., Keleshis, C. and Engelmann, R. (2018). Vertical profiles of aerosol mass concentration derived by unmanned airborne in situ and remote sensing instruments during dust events. Atmos. Meas. Tech. 11: 2897-2910.

Matsui, H., Kondo, Y., Moteki, N., Takegawa, N., Sahu, L., Koike, M., Zhao, Y., Fuelberg, H., Sessions, W. and Diskin, G. (2011). Accumulation-mode aerosol number concentrations in the Arctic during the ARCTAS aircraft campaign: Long-range transport of polluted and clean air from the Asian continent. J. Geophys. Res. 116: D20217.

Matsui, H., Koike, M., Takegawa, N., Kondo, Y., Takami, A., Takamura, T., Yoon, S.J., Kim, S.W., Lim, H.C. and Fast, J.D. (2013). Spatial and temporal variations of new particle formation in East Asia using an NPF-explicit WRF-chem model: North-south contrast in new particle formation frequency. J. Geophys. Res. 118: 11647-11663.

Matsuki, A., Iwasaka, Y., Osada, K., Matsunaga, K., Kido, M., Inomata, Y., Trochkine, D., Nishita, C., Nezuka, T. and Sakai, T. (2003). Seasonal dependence of the longrange transport and vertical distribution of free tropospheric aerosols over east Asia: On the basis of aircraft and lidar measurements and isentropic trajectory analysis. J. Geophys. Res. 108: 8663.

Mönkkönen, P., Koponen, I., Lehtinen, K., Hämeri, K., Uma, R. and Kulmala, M. (2005). Measurements in a highly polluted Asian mega city: observations of aerosol number size distribution, modal parameters and nucleation events. Atmos. Chem. Phys. 5: 57-66.

Peng, Y., Dong, Y., Li, X., Liu, X., Dai, J., Chen, C., Dong, Z., Du, C. and Wang, Z. (2017). Different characteristics of new particle formation events at two suburban sites in northern China. Atmosphere 8: 258.

Peng, Z.R., Wang, D., Wang, Z., Gao, Y. and Lu, S. (2015). A study of vertical distribution patterns of $\mathrm{PM}_{2.5}$ concentrations based on ambient monitoring with unmanned aerial vehicles: A case in Hangzhou, China. Atmos. Environ. 123: 357-369.

Penner, J.E., Dong, X. and Chen, Y. (2004). Observational evidence of a change in radiative forcing due to the indirect aerosol effect. Nature 427: 231.

Pistone, K., Praveen, P.S., Thomas, R.M., Ramanathan, V., Wilcox, E.M. and Bender, F.A.M. (2016). Observed correlations between aerosol and cloud properties in an Indian Ocean trade cumulus regime. Atmos. Chem. Phys. 16: 5203-5227.

Platis, A., Altstädter, B., Wehner, B., Wildmann, N., Lampert, A., Hermann, M., Birmili, W. and Bange, J. (2016). An observational case study on the influence of atmospheric boundary-layer dynamics on new particle formation. Boundary Layer Meteorol. 158: 67-92.

Ramana, M., Ramanathan, V., Feng, Y., Yoon, S., Kim, S., Carmichael, G. and Schauer, J. (2010). Warming influenced by the ratio of black carbon to sulphate and the black-carbon source. Nat. Geosci. 3: 542.

Ramanathan, V., Ramana, M.V., Roberts, G., Kim, D., Corrigan, C., Chung, C. and Winker, D. (2007). Warming trends in Asia amplified by brown cloud solar absorption. Nature 448: 575. 
Ren, L., Zhang, R., Bai, Z., Chen, J., Liu, H., Zhang, M., Yang, X. and Zhang, L. (2012). Aircraft measurements of ionic and elemental components in $\mathrm{PM}_{2.5}$ over Eastern Coastal area of China. Aerosol Air Qual. Res. 12: 1237-1246.

Schrod, J., Weber, D., Drücke, J., Keleshis, C., Pikridas, M., Ebert, M., Cvetković, B., Nickovic, S., Marinou, E. and Baars, H. (2017). Ice nucleating particles over the Eastern Mediterranean measured by unmanned aircraft systems. Atmos. Chem. Phys. 17: 4817-4835.

Seto, T., Kim, S., Otani, Y., Takami, A., Kaneyasu, N., Fujimoto, T., Okuyama, K., Takamura, T. and Hatakeyama, S. (2013). New particle formation and growth associated with East-Asian long range transportation observed at Fukue Island, Japan in March 2012. Atmos. Environ. 74: 29-36.

Takami, A., Miyoshi, T., Shimono, A. and Hatakeyama, S. (2005). Chemical composition of fine aerosol measured by AMS at Fukue Island, Japan during APEX period. Atmos. Environ. 39: 4913-4924.

Takegawa, N., Kondo, Y., Koike, M., Chen, G., Machida, T., Watai, T., Blake, D., Streets, D., Woo, J.H. and Carmichael, G. (2004). Removal of $\mathrm{NO}_{\mathrm{x}}$ and $\mathrm{NO}_{\mathrm{y}}$ in Asian outflow plumes: Aircraft measurements over the western Pacific in January 2002. J. Geophys. Res. 109: D23S04.

Weber, R., Lee, S., Chen, G., Wang, B., Kapustin, V., Moore, K., Clarke, A., Mauldin, L., Kosciuch, E. and Cantrell, C. (2003). New particle formation in anthropogenic plumes advecting from Asia observed during TRACE-P. J. Geophys. Res. 108: 8814.

Wehner, B., Wiedensohler, A., Tuch, T., Wu, Z., Hu, M., Slanina, J. and Kiang, C. (2004). Variability of the aerosol number size distribution in Beijing, China: New particle formation, dust storms, and high continental background. Geophys. Res. Lett. 31: L22108.

Wehner, B., Siebert, H., Ansmann, A., Ditas, F., Seifert, P., Stratmann, F., Wiedensohler, A., Apituley, A., Shaw, R. and Manninen, H. (2010). Observations of turbulenceinduced new particle formation in the residual layer. Atmos. Chem. Phys. 10: 4319-4330.

Yamashita, K., Hayashi, M., Irie, M., Yamamoto, K., Saga, K., Ashida, M., Shiraishi, K. and Okabe, K. (2005). Amount and state of mineral particles in the upper mixed layer and the lower free troposphere over Mt. Raizan, Southwestern Japan: Unmanned airplane measurements in the spring of 2003. J. Meteorolog. Soc. Jpn. 83: 121136.

Yu, F., Luo, G., Bates, T.S., Anderson, B., Clarke, A., Kapustin, V., Yantosca, R.M., Wang, Y. and Wu, S. (2010). Spatial distributions of particle number concentrations in the global troposphere: Simulations, observations, and implications for nucleation mechanisms. J. Geophys. Res. 115: D17205.

Zhang, Q., Zhao, C., Tie, X., Wei, Q., Huang, M., Li, G., Ying, Z. and Li, C. (2006). Characterizations of aerosols over the Beijing region: A case study of aircraft measurements. Atmos. Environ. 40: 4513-4527.

Zhang, Q., Streets, D.G., Carmichael, G.R., He, K., Huo, H., Kannari, A., Klimont, Z., Park, I., Reddy, S. and Fu, J. (2009). Asian emissions in 2006 for the NASA INTEX-B mission. Atmos. Chem. Phys. 9: 5131-5153.

Received for review, March 31, 2018 Revised, November 5, 2018 Accepted, December 7, 2018 